\title{
The Growth of Microbiology
}

\section{The Fifth Marjory Stephenson Memorial Lecture}

\author{
By B. C. J. G. KNIGHT \\ Department of Microbiology, University of Reading \\ ...I melt a gourd fruit into mash, \\ Add honeycomb and pods, I have perceived, \\ Which bite like finches when they bill and kiss,- \\ Then, when froth rises bladdery, drink up all, \\ Quick, quick, till maggots scamper through my brain.... \\ Robert Browning, Caliban upon Setebos
}

I am deeply conscious of the honour of being asked to give this fifth Marjory Stephenson Memorial Lecture; and I am even more conscious of the difficulties of the task. I think that it might be appropriate, sixteen years after the founding of our Society, to look at the origins and growth of the science of general microbiology from which our Society takes its name. History gives perspective and an all-round view which is especially useful in the case of microbiology, with its manifold branches and applications. If not held together by a general conception, microbiology might lose much of its strength and effectiveness.

In attempting to sketch the history of microbiology I have selected what I think are some key phases in its development. I am well aware that in so doing I shall make generalizations which may be questioned. Microbiology grew from many sources, and it would need large tomes to describe in detail its developmental history. All I hope to do is to indicate some of the paths by which we have arrived at the present state of our science.

When one tries to trace the history of a branch of science, the more one reads the more one finds that advance does not come by a logical sequence of steps from man to man, as it were. Mistakes of interpretation, and hypotheses which are subsequently disproved, have their value if they stimulate experiment. In order to abridge, it is inevitable that some individuals will be named, as typical or as having been responsible for key work. As we advance in time, the interactions of the work of different people become more and more complex; and in the present century we find collective work by groups, and more complex systems of communication.

I give this preamble to protect myself from being thought unaware of the great intricacy of the history of microbiology. But also to apologize to, and to pay tribute to, all those in the past and in the present who are not mentioned by name, but whose work has contributed to shape microbiology. This lecture can be only a bare sketch, but I hope an impartial one, although others might give different emphases to different parts of the story. Much of what I say will be familiar; for this I ask your indulgence. 


\section{Origins of microbiology}

The origins of microbiology may be found in those numerous natural phenomena which are manifestations of microbial activity and which men used, or noticed, or suffered, without knowing that they were the effects of microbial growth. One can group these effects under several heads: (1) arts and crafts based on microbial activities; (2) soil fertility; (3) spoilage of stored products; (4) animal and plant diseases. These are ways in which micro-organisms have drawn attention to themselves.

(1) Arts and crafts. The alcoholic fermentation of fruit and plant juices which occurred apparently spontaneously, because of the presence of unsuspected yeasts, was one of the earliest instances of microbial activity of which men made use; and similarly the souring of drawn milks by the action of lactic acid-forming bacteria which found milk an excellent elective culture medium.

Beer-making is more complicated since it involves two stages: the preparation of malt by allowing cereal grain to germinate, thus changing starch to sugar; and the fermentation of the sugar by ubiquitous yeasts. There are Egyptian records of beermaking by this process as early as 2000 B.c. In a Chinese agricultural encyclopaedia of the sixth century A.D. (see Davis, 1945) there are examples, in connexion with domestic economy, of the use of so-called ferment-cakes which must have contained both moulds and yeasts, the combined action of which gave a wine in one process from steamed rice. In beer-making, in the use of ferment-cakes and in the use of leaven from a previous batch of dough in bread-making, the principle involved was that a separated portion of material from one batch, and which could be stored, was used to inoculate a new batch. This is far more sophisticated than those processes which rely on a naturally accompanying microflora, like the yeasts on grapes in wine making.

(2) Soil fertility. Micro-organisms of course play an essential part in decomposing dead plant and animal materials so that the elements contained therein are returned as simple compounds to the soil, and in the fixation of atmospheric nitrogen. Early agricultural practices such as allowing soil to lay fallow and the planting of leguminous crops made use of these microbial activities.

(3) Avoidance of spoilage. The preparation from milk of fermented and soured products, and the making of cheese, are examples of microbial action which gave food products more durable than the raw starting material. Other methods of food preservation in early use involved the provision of environmental conditions unfavourable to microbial growth, such as desiccation, high salt content, low temperatures, unfavourable $\mathrm{pH}$ values.

(4) Animal and plant diseases. Epidemic diseases of man were unavoidably noticed and their characteristics recorded. The similarity of symptoms in given epidemics bred theories about the operations of generally-acting evil forces. One has only to look at the many words in the English language which have been used to denote these sorts of effects : plague, pest, murrain, blast, smut, rust, mildew, mould, rot, putrefaction, blight and so on, to realize how forcibly these manifestations were noted and distinguished.

In speculations about the causes of epidemic animal diseases, as in the great plagues, the question of infection or contagion, as it was originally called, was much 
considered. As early as 1546 Fracastoro published a book, De contagione..., in which he discussed contagion. He clearly described and discussed several diseases, including foot-and-mouth disease in cattle, measles, smallpox and typhus. He compared the spread of these diseases with his observations of the spread of a rot or mouldiness through stored fruit or from fruit to fruit on the plant. But he did not consider the contagious agents as particulate, like the dust from moulds. Fracastoro's book to all intents and purposes had no immediate effect.

There are some lines in Hamlet which show that Shakespeare was a good observer who might have made a good microbiologist. These lines occur in the scene when Hamlet reproves his mother for her marriage with his murdered father's brother. He compares the two brothers, and says:

This was your husband. Look you now, what follows: Here is your husband: like a mildew'd ear Blasting his wholesome brother.

(Shakespeare, Hamlet, Act 3, Scene 4.)

Here is a typically Shakespearean play upon words, the father's ear filled with poison, and the infected ear of wheat blasting its neighbour. What clearer description could one want about the transmission of infection by contact?

The date of Hamlet is about 1600, some 50 years after Fracastoro's book which probably Shakespeare never read, and more than 50 years before William Boghurst wrote his manuscript book Loimographia (1666) in which he described his observations during the Great Plague of London in 1665, recording very acutely what he saw. However, as Bulloch (1938; p. 13) pointed out, Boghurst expressed opinions about the causes of the epidemic which were 'not very far removed from those of the ancients, but which were very different from that urged by Fracastorius 126 years earlier'. This is a very early and perhaps understandable failure of communication in the history of microbiology.

The next great step was, of course, the work of Leeuwenhoek (1632-1723) in showing the existence (1676, 1683: see Dobell, 1932) of such small organisms that the microscope was needed to see them. But it was a long time before micro-organisms were connected with any of the phenomena of microbial growth which I have mentioned. From the time of Leeuwenhoek onwards there was a great development in the construction of microscopes and in the observations made by their aid. The use of the microscope as the main tool for examining these small organisms made it inevitable that their varied shapes should first receive most study. Thus it was that the larger motile forms, the protozoa, should become the prey of zoologists. Other large forms, of filamentous appearance and much less agile habit, were annexed by botanists, to whom fell also the small green algal forms.

Suggestions that micro-organisms such as Leeuwenhoek had described might be agents in any of the phenomena which $I$ have listed were made only more than a century later. Mathieu Tillet (? 1714-91), by a remarkable series of plot experiments, showed (Tillet, 1755) that the disease of wheat called bunt or stinking-smut was transmitted by contact of seed corn with the black dust from the bunt-balls which replaced the healthy grain in diseased ears. He also showed that treatment of seed corn with various alkaline washes decreased the incidence of the disease. 
He examined the black dust microscopically and saw minute spherical bodies of uniform size which he thought were possibly analogous with the dust from puffballs; but he did not recognize them as fungal spores. In a memoir published in 1807 Bénédict Prévost showed that the black dust of the bunt-balls could grow. With the microscope he watched the germination of the spores in water suspension and said that the minute spherical bodies of the bunt dust were the seeds or spores of a microscopic plant, and that it was this living organism which caused the disease of the grain. He also described the lethal effect of copper salts on these spores.

The potato murrain or potato blight which devastated potato crops in Ireland in 1845 and after, and in Europe, and a disease of grape vines first noticed near Margate in the same year which devastated vines in France in the following years, were said by M. J. Berkeley (1846; see Large, 1946, chaps. 2, 3) to be fungal diseases. Although many observers concurred in finding a given fungus associated with the same kind of disease in a given kind of plant, still the evidence remained only circumstantial that a fungus was the cause of a disease. But it became less and less easy to maintain that the fungal growth only followed a weakening of the plant, brought about in some other way which was the real cause of the disease.

The observation of the existence of a micro-organism capable of entering the animal body and there multiplying to cause disease was recorded by Agostino Bassi (1773-1856) in his now celebrated book Del mal del segno...(published in 1835) about one of the diseases of silk worms then causing great losses to the silk industry in northern Italy. From many experiments Bassi came to the conclusion that the disease was really contagious. He transmitted the disease from sick larvae to healthy ones by a technique which involved removing a portion of epidermis from a sick silk-worm, flaming the larva, touching the underlying tissues with a previously flamed pin, and then scratching a healthy silk-worm with it. Bassi recognized the causative organism, which formed the characteristic white efflorescence on the larvae after death, as a fungus. It is understandable that it was fungi, giving discernible growth on the host, which should first have been recognized as probable causes of certain animal and plant diseases.

P. F. Bretonneau (1778-1862) was the founder of the doctrine of the specificity of animal disease. He deduced from many clinical and pathological observations that it was the nature of the morbid cause rather than its intensity which explained the different pictures presented by different diseases. Bretonneau (1826) thought that diphtheria and typhoid fever developed under the influence of specific contagious principles or reproductive agents. He did not, however, connect these reproductive agents with any of the microscopic forms which were well known and much discussed by microscopists in Bretonneau's time.

The demonstrations of Prévost and Bassi of fungal diseases in plants and silk worms, respectively, appear to have had little immediate effect in making easier the acceptance of a germ theory of animal, particularly human, disease, although their work, together with that of Cagniard-Latour, Schwann and Kützing on the connexion of yeast as a living organism with fermentation, in the 1830's, and the theoretical conclusions of Henle (1840), stimulated the microscopical examination of pathological materials. Various human dermatophytes were described during the period 1840-50 (e.g. Schönlein, 1839; Gruby, 1842, 1843, 1844; see Ainsworth, 1951; Bulloch, 1938). But it needed the work of Pasteur (beginning 1857; see bibliography) 
on the role of bacteria in the causation of specific biochemical effects, and that of Robert Koch (1878) on anthrax, before the role of bacteria in animal disease was finally accepted.

\section{Biochemistry}

It is convenient at this point to turn to that other main stream of study which eventually fused with microbial studies, namely the chemistry of biological compounds, which led to the chemistry of biological processes, to biochemistry. From the earliest records there is evidence of the chemical study of biological products, no distinction being made between inorganic and organic materials. In the seventeenth century chemistry developed in two directions typified by Agricola the father of metallurgy, and by Paracelsus the founder of medical chemistry. Paracelsus used mercury and inorganic mercurial compounds in the treatment of syphilis-the line which Ehrlich developed successfully so many years later. Some of the followers of Paracelsus tried to extract from biological materials their active medicinal principles; many essential oils were separated, and numerous simple organic compounds obtained by dry distillation.

By the end of the eighteenth century organic compounds began to be investigated from a new point of view, i.e. as substances in themselves rather than as substances for use in pharmacy or in various arts and crafts. Lavoisier (1789) investigated vinous fermentation and showed that the conversion of sugar into ethanol and $\mathrm{CO}_{2}$ could be expressed quantitatively. This was something new and marks an important step in the chemical investigation of biological processes.

From the beginning of the nineteenth century organic chemistry emerged as a well defined science, concerned with the development of chemical theory, the determination of structures, and the synthesis of carbon compounds, many derived from biological sources. After its coal-tar debauches organic chemistry returned once more to Mother Nature, to study the most complex components of the chemical anatomy of the cell.

In the study of fermentation and putrefaction the chemistry of biological compounds began to change into the chemistry of the processes whereby they were formed, into biochemistry. The study of the chemical effects of micro-organisms began in pronounced form with the controversy about the nature of yeast and its action in fermentation. In the 1830's Cagniard-Latour (1836), Schwann (1837) and Kützing (1837) independently concluded that yeast was a living organism, and performed experiments which implicated the yeast granules as the cause of vinous fermentation. The theory of the biological causation of fermentation developed by these and subsequent workers met strong opposition from chemists who were loath to admit that fermentations were the result of biological activity. It must be remembered that this work was taking place in a context where chemistry was beginning successfully to determine the structures of biological compounds and to make them by purely chemical reactions. 'Vital forces' were retreating before chemistry.

By the middle of the nineteenth century the conditions were ripe for the fusion of the two streams I have indicated: on the one hand, the study of phenomena potentially caused by micro-organisms; and on the other, the chemistry of biological products and the processes whereby they are formed. Undoubtedly if Pasteur had 
not arrived at that time this fusion would have taken place. Too many men were then working as professional scientists for it to have been long delayed. But Pasteur did arrive, and there is no clearer example of the right man at the right time. The fusion took place and there came that explosive reaction from which microbiology, the science of microbes*, was born.

\section{Aseptic technique}

Before continuing to describe the evolution of microbiology which began with the work of Pasteur it is convenient to intercalate a brief consideration of the question of spontaneous generation or heterogenesis, since the experimental study of this rather metaphysical question led to the establishment of sound aseptic techniques - a crucial point in the growth of microbiology. Whether new living forms might appear from non-living materials was a very ancient question. The publications on this topic by Redi (1668), Joblot (1718), Spallanzani (1765), Schwann (1837) and others contributed greatly to defining the experimental conditions necessary to prepare and maintain sterile nutrient infusions. This work culminated in that of Pasteur and John Tyndall which showed that microbial growth in heat-sterilized nutrient infusions occurred only when defects in technique permitted viable particles carried by the air to enter vessels containing the heat-sterilized media. One of John Tyndall's important contributions was the demonstration of the greater heat tolerance of some bacterial forms (spores) as compared with other (vegetative) forms. His method of sterilizing media by intermittent heating, with intervals to allow heat-tolerant spores to germinate to heat-sensitive forms, was worked out then; this procedure we now call Tyndallization. Some of the apparatus with which Tyndall's work was done here is exhibited in the gallery which surrounds this lecture theatre. His classic book The Floating Matter of the Air was published in 1881 .

The practical outcome of this work on the question of spontaneous generation or heterogenesis was the realization of the ubiquity of viable minute air-borne forms and the establishment of aseptic techniques whereby experiments could be made under controlled conditions, so that chance contamination should not vitiate them. This provided an essential technical basis for the advance of microbiology.

\section{Microbiol physiology}

I turn now to the development of microbial physiology stemming from the work of Pasteur. Pasteur, trained as a chemist, made his first contact with microorganisms through his efforts to resolve the racemic mixture of $\mathrm{D}$ - and L-tartaric acids, when he observed that a mould was capable of decomposing one component only of the racemic mixture, leaving the $\mathrm{D}$-form undecomposed. Thus the chemical problem posed by the enantiomorphs of tartaric acid, itself a product of winemaking, brought Pasteur in direct contact with a beautiful example of specific microbial action. His interest in optical activity lead him to study optically active

\footnotetext{
* The word 'microbe' was coined by the surgeon C. E. Sédillot (1878) to designate any organism so small as to be visible only under the microscope. Pasteur rarely used this word, preferring to use 'micro-organism'. He suggested later that the science of microbes might be called 'microbie' or 'microbiologie' which he regarded as having a wider meaning than 'bactériologie' (see Bulloch, 1938, pp. 187, 397; Dubos, 1950, p. 188).
} 
amyl alcohol, another fermentation product, and this led him to study those fermentations which yielded lactic, acetic and butyric acids. As it happened, these fermentations were caused by bacteria. Through his work the causal connexion of the chemical action with the growth of specific bacteria was firmly established. Bacteria as agents of chemical change came to the fore.

Soon after, bacteria were shown to be agents of animal disease by the work of Robert Koch and of Pasteur and his associates in the 1870's, on anthrax. Then it was that Koch applied in practice the criteria to be used in order to prove that a given organism was the causative agent of a given disease, subsequently referred to as 'Koch's postulates'; the conditions had in fact been stated theoretically by Henle in 1840 (see Fildes \& McIntosh, 1920).

During the next 20 years, after the proof that anthrax bacilli were the cause of that disease, many more bacteria pathogenic for animals were discovered, in particular by the school led by Koch, whose techniques for the isolation and identification of bacteria (e.g. plating separated viable units on the surface of culture media solidified at first by gelatine, later with agar-agar) were cardinal developments in bacteriology. There is no need to expand this here, except to suggest that the importance of this diagnostic aspect of bacteriology, in connexion with medicine, resulted in a departmentalization which, on balance, retarded the study of the organisms themselves.

I wish now to consider some of the general results of Pasteur's fermentation studies. The important conceptual step was that Pasteur looked upon the chemical activities of micro-organisms as directly related to their physiological processes-the processes whereby they lived and multiplied. That the chemical compounds which had been the initial point of interest were the result of bacterial action was one thing, but that these compounds were essential products of the metabolismthe biochemical processes of multiplication-of the organisms was a much more pregnant idea. It was this conception that Pasteur maintained against the opposition of chemists led by Liebig (see for example, Liebig, 1840, 1870), who held that the ferments involved were merely catalysts, perhaps produced by, but not causally connected with, the growth of cells. It was not until after Pasteur that the apparent contradiction between the two conceptions was resolved.

To summarize the effect of Pasteur's work in microbial physiology I cannot do better than quote what Marjory Stephenson wrote in her paper read at the Congress held in 1946 to commemorate the 50th anniversary of Pasteur's death; she wrote:

Amongst the many remarkable aspects of this wonderful man is the attitude he adopted in the biological interpretation of the chemical effects produced by microbes. We are most of us familiar with the attitude of the chemist when he turns to microbiology for the solution of his problems; he then expects to use his microbes as a reagent but almost always neglects to study the problem from the point of view of the cell itself. Many chemists never attain the biological attitude, others only after long and painful experience. How different was the case of Pasteur who admittedly turned to fermentation to solve a problem in sterioisomerism but immediately adopted in his studies a most pronounced biological viewpoint. Fermentation was not regarded as a problem in isolation but as the chemical expression of a method of life-la vie sans air. Every other chemical activity of the organisms as it was disclosed was related to cell physiology and thus was the foundation of bacterial metabolism well and truly laid.

Such was the prestige and vigour of Pasteur that he permeated the thought of his time 
and directed it along his own lines. Nitrification, nitrogen fixation, sulphur and iron oxidation and all the fundamental discoveries of the Pasteur period were interpreted in terms of cell physiology and there can be no doubt that the surprisingly rapid advance made between 1858 and the end of the century was due to this outlook.

In spite of the fact that what may be called the Pasteur outlook stimulated so much brilliant discovery, it took little account of the rapidly accumulating knowledge of enzyme action to interpret the physiological processes involved. One can get an excellent conspectus of the state of knowledge about enzymes at the end of the nineteenth century from Reynolds Green's book The Soluble Ferments and Fermentations, published in 1899. The following quotation from the preface to this book indicates the quality of biochemical thinking about enzymes at that time:

The more recent work takes the subject beyond the stage at which it was left by Pasteur, showing us that precisely similar operations are incidental to the life of the higher organisms. It thus becomes necessary to inquire into the relationship of protoplasm to metabolism, and to the association of ferments or enzymes with the living substance, and so to establish the intimate relationship of fermentation to the ordinary metabolic processes. It becomes possible to go further than this, and to consider by what chemical or physical processes the observed changes or decompositions are affected by protoplasm or by its secretions.

This foreshadowed a comparative biochemistry which only began really to develop much later.

When Reynolds Green was writing there were appearing in Paris, in the years 1898 to 1902 successively, the four large tomes, in all about 3000 pages, of the Traité de Microbiologie written by Émile Duclaux, Pasteur's chemical colleague and his successor as Director of the Institut Pasteur. Duclaux's Traité de Microbiologie shows uniquely what microbiology was at the beginning of the twentieth century. These four volumes collected and organized the very large amount of work in the field of chemical microbiology which had been accomplished up to then. I am amazed, in reading them, not only by the volume and quality of the work which Duclaux organized, but by the modern tone of his synthesis. In many respects the tables of contents read like the headings for a course of modern microbiology. It seems to me extraordinary that this great work should not have had a greater impact in effecting an earlier fusion between biochemistry and the more biological aspects of microbiology than in fact took place.

The demonstration by $\mathbf{E}$. Büchner in 1897 that yeast cells could be broken to yield a juice which could perform alcoholic fermentaton was a key step in enzyme studies. This brought the study of fermentation into a new field of experiment: the study of cell-free biochemical processes. The school of Harden (1911 and after) in Britain and the largely German-led schools in Europe gave the great advances in our knowledge of the processes of glycolysis which took place in the second and third decades of the present century. But as Marjory Stephenson (1946) went on to comment in the paper from which $I$ have already quoted:

It is moreover noticeable that in periods, such as that immediately following Büchner's achievement, when the study of cell physiology tends to be disregarded, general microbiology advances only slowly, and within my own personal experience the same holds good; microbiology can only be successfully pursued as the study of a cell in relation to its environment, whether that environment be the outside world or the tissues of the host animal or host plant. 
When Duclaux wrote his treatise at the beginning of the twentieth century he was conscious of the rate of development of microbiology, and of the future impossibility of any one man writing such a book. In the preface to vol. I (1898) he said:

... and when one thinks that microbiology is joined by the study of enzymes to one of the most unknown regions of chemistry, by the study of proteins to one of the most difficult, by the study of the microflora of earth, air and water to general hygiene, by the study of fermentation to the whole of physiology, by that of viruses [pathogenic microbes] and poisons to the whole of medicine, one cannot but conclude that the day is near when a microbiologist ought to be at one time so many things that this will no longer be possible; he will have to choose.

In fact, workers with micro-organisms did choose, and there was rapid and successful study of many fields of microbial activity. This led to a fragmentation of microbiological studies into separate fields of application, with consequent difficulties of inter-communication and a stress on the results of microbial action rather than on the physiology of the micro-organisms whereby they multiply in their environments. The study of microbial physiology I take to be a more basic and unified study than the study of the consequences-viewed anthropocentrically-of microbial growth, which reflect only some aspects of physiology. As Kluyver (1956) remarked:

Since Pasteur's startling discoveries of the important role played by microbes in human affairs, microbiology as a science has always suffered from its eminent practical implications.

This fragmentation of microbiology into many fields of application helps to explain the lag in the integrated study of microbial physiology which took place after Pasteur's work. Marjory Stephenson deliberately chose bacteria as tools for biochemical studies, in order to use organisms 'more susceptible to laboratory control'. From 1920 onwards her school laid the basis of the modern study of bacterial metabolism. Her book Bacterial Metabolism (1930) was fundamental in co-ordinating and stimulating work in this field, with its stress that metabolic enzymes could not

profitably be considered apart from the systems of which they form part i.e. from the action of other enzymes and also from that still mysterious mechanism by which the cell coordinates its separate systems in its own service. (Introduction to Bacterial Metabolism, 1930, p. 9.)

\section{Microbial nutrition}

The study of bacterial nutrition also gained momentum in the 1920's. From the time of Pasteur some fungi and yeasts had been grown in simple defined media, but it was attempts to grow certain animal pathogenic bacteria in laboratory culture which focused attention on their exacting nutritional requirements. Two examples may be mentioned.

Twort \& Ingram (1913) found that Johne's bacillus, Mycobacterium johnei, which causes a chronic enteritis in cattle, could not be grown in complex bacteriological media unless these were supplemented with products of other mycobacteria which could grow in the unsupplemented media. In the 1920's work on the laboratory cultivation of Haemophilus influenzae showed that this organism would not grow in autoclaved complex bacteriological media until these were supplemented with a heat-labile factor and a heat-stable factor from blood. The naming of the heatlabile factor as a V or vitamin factor indicates that this work was being done in the context of animal vitamin studies. 
The analytical approach, by the fractionation of complex culture media, was used in particular by J. H. Mueller (see J. H. Mueller, 1940) at Harvard, by the group led by Sir Paul Fildes (Medical Research Council Unit for bacterial chemistry, first at the London Hospital, 1929, and later at the Middlesex Hospital, 1934; see Knight, 1936, 1945), by André Lwoff and co-workers at the Institut Pasteur (see Lwoff, $1932,1944)$ and other workers. Eventually numerous microbial growth factors were identified.

Wider implications of nutritional studies became evident when it was found that the same growth factors were essential nutrients for very different organisms, and that micro-organisms which did not require these substances as nutrients did indeed synthesize them. Cross-links with animal nutrition came with the finding that vitamin $B_{1}$, thiamine, was an essential nutrient for some micro-organisms. The recognition of an essential nutrient common to bacteria and animals stimulated work with bacteria, since these grew so much faster and were easier to handle. Later work established the reciprocal relation that some microbial growth factors were also animal vitamins.

The next step was the finding of functions for some of these animal vitamins and microbial growth factors as components of enzyme systems of general distribution in many kinds of organisms. It eventually became clear that the identification of essential nutrients was a way of finding parts of essential metabolic mechanisms commonly used by very different organisms, and that nutrient requirements reflected the abilities of different organisms to synthesize-in whole or in part-these components of generally used metabolic mechanisms (see Knight, 1936, 1945; Lwoff, 1932, 1944). It was to emphasize this that Fildes (1940) suggested the term 'essential metabolite' for use in place of the term 'growth factor', since the latter indicated a more limited status as a nutrient, while the term essential metabolite indicated a more general function as an essential component of the living cell. An essential nutrient for a given organism was an essential metabolite which that organism could not synthesize.

\section{Biosynthesis and microbial genetics}

Theories about the inter-relationship of nutritional requirements with ability in biosynthesis, based upon the comparative nutrient requirements of very different micro-organisms, and the possible relation of these differences to an evolutionary loss of ability to synthesize (Lwoff, 1932, 1944; Knight, 1936) were given a clearcut basis by the work of Beadle and Tatum. If such losses in ability to synthesize were based on mutation and selection as required by modern concepts of evolution, then the capacities for the synthesis of essential metabolities in micro-organisms should be determined by genes, which should be subject to mutation as in other organisms. This is what Beadle \& Tatum (1941) found in the successful production, by the use of mutagenic reagents, of nutritionally deficient or biochemical mutants of Neurospora sp. Biochemical mutants were later obtained from bacteria.

The way was thus opened for the study of biosynthetic and metabolic pathways by the use of micro-organisms blocked at selected steps in possible reaction chains. There is no need to emphasize how useful such mutants have been in the study of metabolic pathways. My predecessor D. D. Woods in the Inaugural Lecture (1953) 
of this series discussed in detail the integration of research on the nutrition and metabolism of micro-organisms.

In the ways I have mentioned, from the 1920's on, it thus became possible to begin to study in detail how micro-organisms change the compounds of their environment into more of themselves. How they affect their environments, whether in an industrial process, in spoilage, in soil fertility, or in disease, are the results of their multiplication and the cellular metabolism which this involves.

When it was established that most characters of bacteria are controlled by hereditary units analogous to genes in classically sexual forms, wide possibilities began to emerge for the study of the mode of inheritance of characters. Such studies gave birth to the new field of microbial genetics which is now having such farreaching developments. This work with micro-organisms has opened new perspectives in the study of biological inheritance and variation in general.

\section{Microbiology}

The physiological viewpoint in microbiological studies was clearly developed by Marjory Stephenson in the Introduction to her book Bacterial Metabolism (1930), and it remained a guiding principle through the rest of her life. How she visualized these physiological studies as contributing to our knowledge of the behaviour of micro-organisms in nature was summed up in the celebrated table of levels of research which she gave at the inaugural meeting of our Society in February 1945.

This table has often been mentioned; it was recorded briefly in an unsigned report of the inaugural meeting of the Society for General Microbiology published in Nature in February 1945, and in a modified form in D. D. Woods's Memorial Lecture in 1953. The actual table itself has not hitherto been published. I am glad to be able to show a picture of it today; it shows some interesting details not given in earlier references to it (Plate, fig. 1, and Appendix).

I am particularly glad to be able to show this table because it makes so clear the broad biological outlook of one whose life-work was mainly in the field of chemical microbiology. I hope I have not given the impression that I think that all microbiology is chemical microbiology. I do not; that is why I have often used the expression microbial physiology, meaning the functioning of the whole organism in its environment, which will include other organisms. This functioning is also expressed in biological terms, as in the questions of heredity, variation and competition.

You will see from this table (see Plate, fig. 1; and Appendix, p. 369) that the various levels of microbiological investigation, which Marjory Stephenson formally separated, include almost all biological aspects, at least by implication and extension, for which the most biological biologist could wish; for example, in the study of mixed cultures growing in natural environments. The time sequence indicated in the right-hand side of the table shows microbiology proceeding, in the left-hand column, to more and more detailed investigations, and more and more simplified systems. But one has only to study the content of this right-hand column to see that it embraces all aspects of the biological activity of the organisms. Furthermore, from the point of view of biology in general, one can remember that, because of their extremely wide range of physiologies, micro-organisms give one of the most fruitful and convenient fields for the study of that conception of the unity of biochemistry at the cellular level which Kluyver did so much to emphasize. 
Marjory Stephenson's table sums up very well the attitude of the workers in many different fields of microbiology who came together to found our Society sixteen years ago, among whom she was one of the most far-sighted. In the minds of the founders of our Society there was a pretty clear idea of the need for attempting to. weld the various parts of microbiology into a whole, or at least of helping to avoid the difficulties of communication between the different parts of microbiology which arise primarily from those 'eminent practical implications' which Kluyver remarked upon. In the last twenty years we have seen an enormous development of microbiology, especially of those fields concerned with bacteriophage, plant and animal viruses, microbial genetics, adaptive or inducible enzymes and the fine structure of cells.

Our Society has attempted to maintain a unified outlook on microbiology as the study of the organisms in their environments, how they multiply and how they may change. This is a central position from which microbial activities can be investigated and controlled. Our Society has tried to foster this unifying role by its meetings and through its Journal. The Symposia have had as objectives to bring together different kinds of work around selected topics, some narrower, some wider. Some of the topics have concerned rapidly developing fields, such as bacterial anatomy, viruses and microbial genetics. With other symposia the intention has been to survey wider fields, more slowly developing perhaps because more complex; for example the symposium on Microbial Ecology (1957) and to-morrow's symposium on Microbial Reaction to Environment (1961).

In the eighteenth century and the first half of the nineteenth century the means of scientific communication were relatively modest, and the difficulties of communication between different fields of microbiology seem to have been ideological, rather than practical. During the last fifty years the rate of publication has increased year by year, latterly at a daunting speed. Now the difficulty is not so much the lack or badness of communication but a plethora of print which tends to encourage splitting into highly specialized fields.

Our Journal tries to help in welding microbiology into a whole, or at least in keeping within one pair of covers a fairly catholic cross-section of what we think of as microbiology. This is not always easy. I think I might now make a plea as an editor that microbiologists should practise a certain continence in writing papers, should preserve a certain scientific chastity, as it were. To support this plea I would instance the relatively short list of papers which Marjory Stephenson wrote during nearly thirty years of work. Characteristically she did not publish until a piece of work had been well established and had reached a certain degree of completeness.

In conclusion I wish to show a picture (Plate, fig. 2) of the last paragraph of the abstract of the paper which Marjory Stephenson read at our Inaugural Meeting in 1945, because it shows in her own clear language her vision of the function of our Society:

Unless work is to grow first stale and then sterile it must be refreshed by contacts with work at other levels. Moreover as knowledge increases and technique becomes more difficult interdepartmental collaboration is strongly indicated, a development which this society may do much to foster.

(See Appendix for the complete abstract.) 
I hope we may all bear in mind the difficulties of this task of integration and also the great value of attempts to achieve it. This needs our continuous attention as new branches of microbiology continue to proliferate.

\section{APPENDIX}

Author's abstract of a paper read at the Inaugural Meeting of the Society for General Microbiology on 16 February 1945 at the London School of Hygiene and Tropical Medicine.

\section{By Marjory Stephenson}

The hopes which I build up around this Society can be summarized in two words, contacts and motion. At the outset I should like to confess that in the labelling of microbiological work I am somewhat of a heretic for I have come to believe that certain fashionable words are more mischievous than helpful. Pure science for example implies the existence of an impure variety whilst fundamental research suggests that someone else is occupied in superficial activities. Such terms are apt to introduce discord in the family, which is not one of the aims of our new society; I propose to banish them therefore from this discussion.

\section{Levels of microbiological investigation}

A Mixed cultures growing in natural environments

Early Pasteur Period 1858-. Early studies on soil microbiology, and fermentation. Modern work on marine, river and lake populations, soil and ruminant digestion.

B Pure growing cultures in laboratory Later Pasteur Perion 1876-. Isolations in pure media culture and the identification of the causal agents of many infectious diseases, specific fermentations and chemical changes in soil

C Non-proliferating cells in pure culture on chemically defined substrates

Early studies (1919- ) on intermediary processes of fermentation use of poisons, inhibitors and fixatives. Early enzymes studies-oxidations, reductions, deaminations, decarboxylations etc.

D Pure growing cultures in highly purified media

Detailed study of growth requirements, microbial vitamins, nutritional antagonism, chemo-therapeutics, microbiological assay. 1930-

E Cell-free enzymes and co-enzymes on pure substrates

Development of C. Greater precision in knowledge of fermentation processes and correlation with chemical activity of animal and plant tissues. Action of some growth factors as co-enzymes and of some soluble toxins as enzymes. 1940-

Nevertheless members here present work in many different fields or, as $I$ have indicated in my diagram, at different levels which $\mathrm{I}$ have labelled $\mathrm{A}, \mathrm{B}, \mathrm{C}, \mathrm{D}, \mathrm{E}$ without any prejudice as to which is higher or lower still less which is fundamental or superficial. These levels are characterized by differences of technical approach. Level $\mathbf{A}$ is particularly characteristic of the early period of microbiology which began with the publication of Pasteur's first paper on fermentation in 1858. It comprises studies of mixed populations in natural media, and it will be recalled that much early work on fermentation, putrefaction and chemical changes in soil belongs here; but important modern work is done at this level, including the study of river, lake and marine populations, the enzymes of the soil and the chemical changes occurring in the rumen.

Level $\mathrm{B}$ involves the simplification of the biological material by the use of pure cultures; to this level belong the great triumphs of medical bacteriology where specific organisms were proved to be the causal agents of specific diseases or of chemical changes in soil or of well characterized fermentations; the greater part of medical and epidemiological bacteriology is still done at this level and almost every new discovery must start here. It is, however, 
important to note the limitations of the method; you can by this technique attribute the overall effect to a given organism but you can learn little or nothing of the mechanism by which the effect is brought about. For example you can attribute a certain form of gas gangrene to a certain type of $\mathrm{Cl}$. welchii but you can little of the mechanism by which the organism achieves the result.

At level $\mathrm{C}$ you proceed to the simplification of the substrate; you dissociate chemical activity from simultaneous growth and by the use of poisons and inhibitors you begin to unravel the mechanisms and stages by which the organism in pure culture produces its chemical effects. You can begin to study the cell as an association of enzyme systems. Neuberg's work on alcoholic fermentation was done at this level and the early work of the Cambridge School.

In $\mathbf{E}$ you proceed further and begin to separate the enzymes themselves and show how each produces its effect on its own particular substrate. Thus in the case of $\mathrm{Cl}$. welchii (type A) the toxin or lethal factor has been partially purified and shown to be an enzyme, lecithinase, which achieves its dire results by disrupting the lecithin of the blood cells and tissues whilst the 'invasive factor' has been identified with hyaluronidase which by the destruction of hyaluronic acid facilitates the spread of the infective agent.

But it is not the filterable enzymes alone which can be separated and purified; several methods now exist for breaking up the bacterial cell. In the case of Esch. coli, for example, we have been able to extract several of the enzymes operating in the long chain of events by which the carbohydrate molecule is disrupted to the final stable products of fermentation. Examples of work at this level are flowing in fast and gathering in momentum and volume.

As we proceed from $\mathrm{A}$ to $\mathrm{E}$ first the biological agent then the substrate then again the biological agent are simplified till the process first discerned at $B$ as cause and effect is finally shown to consist of an ordered march of complicated events.

But it is obvious how dependent on each other are the workers at different levels. Facts established at $\mathrm{A}$ and $\mathrm{B}$ provide the starting-point for work at $\mathrm{C}, \mathrm{D}$ and $\mathrm{E}$. But movement must be in both directions. For instance, the association of certain strains of Group D streptococci with epidemics of neo-natal diarrhoea have been tied up with the presence of the enzyme tyrosine decarboxylase; the ball was then tossed back to level B for epidemiological verification and animal experiment.

Unless work is to grow first stale and then sterile it must be refreshed by contacts with work at other levels. Moreover as knowledge increases and technique becomes more difficult interdepartmental collaboration is strongly indicated, a development which this society may do much to foster.

(Signed) Marjory Stephenson

\section{REFERENCES}

Arnswonth, G. C. (1951). A century of medical and veterinary mycology in Great Britain. Trans. Brit. mycol. Soc. 34, 1.

Bassi, Agostino (1835). Del mal del segno.... 1958: English translation by P. J. Yarrow, ed. G. C. Ainsworth, Phytopath. Class. (Amer. phytopath. Soc.), no. 10.

Beadle, G. W. \& Tatum, E. L. (1941). Genetic control of biochemical reactions in Neurospora. Proc. nat. Acad. Sci., Wash. 27, 499.

Berkeley, M. J. (1846). Observations botanical and physiological on the potato murrain.... 1948: Phytopath. Class. (Amer. phytopath. Soc.) no. 8. East Lansing, Michigan, U.S.A.

Boghurst, William (1666). Loimographia; an account of the great plague of London in the year 1665. 1894: now first printed from the British Museum Sloane MS. 349 for the Epidemiological Society of London. Edited by J. F. Payne. London: Shaw \& Sons.

Bretonneau, P. F. (1826). Des inflammations speciales du tissue musqueux et en particulier de la diphthérite.... Paris: Crevot.

Brown, J. C. (1913). A History of Chemistry. London: J. and A. Churchill.

Büchner, E. (1897). Alcoholische Gärung ohne Hefezellen. Ber. 30, 117.

Bulloch, W. (1938, reprinted 1960). The History of Bacteriology. Oxford University Press. 
Cagniard-Latour, C. (1837). Mémoire sur la fermentation vineuse. C.R. Acad. Sci., Paris, 4, 905.

Cagniard-Latour, C. (1838). Mémoire sur le fermentation vineuse. Ann. Chim. 68, 128.

DAvis, T. L. (1945). Introduction to English translation by Huang Tza-Ch'ing and Chao Yun-ts'ung of: The Preparation of Ferments and Wines by Chia Ssu-Hsieh of the later Wei dynasty. Harvard J. Asiat. Studies, 9, 24.

Dobell, C. (1932). Antony van Leeuwenhoek and his 'Little Animals'. London: John Bale, Son and Danielsson.

Doetsch, R. N. (editor, 1960). Microbiology: Historical Contributions from 1776-1908. New Brunswick, New Jersey, U.S.A.: Rutgers University Press.

Dubos, R. (1950). Louis Pasteur: Free Lance of Science. Boston: Little, Brown and Co. (with illustrations). [1951, London: Gollancz.]

Duclaux, E. (1896). Pasteur: histoire d'un ésprit. Sceaux: Imprimerie Charaire et Cie. 1920, English translation by Erwin F. Smith \& Florence Hedges. Philadelphia and London: W. B. Saunders Company.

Duclaux, E. (1898-1902). Traité de Microbiologie. 4 tomes. Paris: Masson et Cie.

Fildes, P. \& McIntosh, J. (1920). The aetiology of influenza. Brit. J. exp. Path. 1, 119.

Fildes, P. (1940). A rational approach to research in chemotherapy. Lancet, i, 955.

Fracastoro, G. (1546). De contagione.... 1930: English translation by W. C. Wright. New York: G. P. Putnam's Sons. See Bulloch (1938), pp. 9-13.

Green, J. Reynolds (1899). The Soluble Ferments and Fermentations. Cambridge University Press.

Gruby, D. (1842, 1843, 1844). See Ainsworth (1951); Bulloch (1935), pp. 165-6.

Harden, A. (1911). Alcoholic Fermentation. (1914, 2nd edition; 1923, 3rd edition; 1932, 4th edition.) London: Longmans, Green and Co.

Henle, J. (1840). See Fildes \& McIntosh (1920); Bulloch (1938), pp. 163-5.

Joвlot, L. (1718). Descriptions et usages de plusieurs nouveaux microscopes tant simples que composez; avec de nouvelles observations faites sur une grand nombre d'insectes et sur d'autres animaux de diverses espèces qui naissent dans des liqueurs preparées et dans celles qui ne le sont point. Paris: Collombat. See Bulloch (1938), pp. 70-1.

Kluyver, A. J. \& van Niel, C. B. (1956). The Microbe's Contribution to Biology. Cambridge, Massachusetts, U.S.A.; Harvard University Press.

KNIGHT, B. C. J. G. (1936). Bacterial nutrition; material for a comparative physiology of bacteria. Spec. Rep. Ser. med. Res. Coun., Lond. no. 210.

KNIGHT, B. C. J. G. (1945). Growth factors in microbiology; some wider aspects of nutritional studies with micro-organisms. Vitam. \& Horm. 3, 108.

Косн, R. (1878). Untersuchungen über die Aetiologie der Wundenfectionskrankheiten. Leipzig: Vogel. (1880): English translation by W. W. Cheyne: Investigations into the Etiology of Traumatic Infective Diseases, no. 88. London: New Sydenham Society. See Doetsch (1960).

KüTzING, F. (1837). Microscopische Untersuchungen über die Hefe und Essigmutter nebst mehreren andern dazu gehörigen vegetabilischen Gebilden. J. prakt. Chem. 2, 385. See Bulloch (1938), pp. 50-3, 378.

Large, E. C. (1946). The Advance of the Fungi. London: Cape.

Lavoisier, A. L. See, for example (1789). Traité elementaire de chymie, 2 tomes. Paris. See Brown (1913), pp. 288-9; Bulloch (1938), pp. 43-4.

LeEuWenhoek (1676, 1683). See Dobell (1932).

Liebig, J. von (1840). Organic Chemistry in its Application to Agriculture and Physiology. Ed. from MS. by Lyon Playfair. London: Taylor and Walter.

Liebig, J. von (1870). Ueber Gärung über Quelle der Muskelkraft und Ernährung. Leipzig and Heidelberg: Winter.

Lwoff, A. (1932). Recherches biochimiques sur la nutrition des protozoaires; le pouvoir de synthèse. Paris: Masson et Cie.

LwoFf, A. (1944). L'évolution physiologiques; itudes des pertes de fonctions chez les microorganismes. Paris: Hermann et Cie.

Muelrer, J. H. (1940). Nutrition of the diphtheria bacillus. Bact. Rev. 4, 97. See Knight (1945). 
Pasteur. The contribution of Pasteur to microbiology was, of course, cardinal : it has been much studied. Among outstanding books are those by Duclaux (1896), Bulloch (1935), Dubos (1950). Pasteur's Études sur la bière (1876) was published in English in 1879, translated by F. Faulkner and R. C. Robb (London: Macmillan). The collected publications and unpublished material have been collected in Oeuvres de Pasteur réunies par Pasteur Vallery-Radot (1933-39). Paris: Masson and Cie.

Pasteur, L. (1857). Mémoire sur la fermentation appelée lactique. C.M. Acad. Sci. Paris, 45, 913. See Doetsch (1960).

Pasteur, L. (1858). Sur la fermentation appelée lactique. Ann. chim. Phys. $3^{\circ}$ ser. 52 , 404.

Prévost, BÉnÉdict (1807). Memoir of the immediate cause of bunt or smut of wheat and of preventives of bunt. 1939: English translation by G. W. Keitt, Phytopath. Class. (Amer. Phytopath. Soc.), no. 6. Menasha, Wisconsin, U.S.A.

REDI, F. (1668). Esperienze intorno alla generazione degl'insetti. Firenze. English translation by M. Bigelow: Experiments in the Generation of Insects. Chicago: Open Court Publ. Co. See Bulloch (1938), pp. 67-70, 392.

Schönlein, J. L. (1839). Zur Pathogenie der Impetigines. Arch. Anat. Physiol., Lpz. p. 82.

SchWANn, T. (1837). 1847: English translation by H. Smith; Microscopical Researches into the Accordance in the Structure and Growth of Animals and Plants. London: Sydenham Society. Note on pp. 197-8 about yeast and fermentation. See Bulloch (1938), pp. 48-55, 296; Doetsch (1960).

SÉdilıot, C. E. (1878). See Bulloch (1938), pp. 187, 397.

Society for General Microbiology (1945). Report of Inaugural Meeting. Nature, Lond. 155, 796.

Society for General Microbiology (1957). Seventh Symposium: Microbial Ecology. Edited by R. E. O. Williams \& C. C. Spicer. Cambridge University Press.

Society for General Microbiology (1961). Eleventh Symposium: Microbial Reaction to Environment. Edited by G. G. Meynell \& H. Gooder. Cambridge University Press.

Spallanzani, Lazzaro (1765; orig. edn.). See, Experiences pour servir a l'histoire de la generation des animaux et des plantes par M. l'Abbé Spallanzani, avec une ébauche de l'histoire des êtres organisés avant leur fecondation par Jean Senebier. 1785. Geneva: Barthelemi Chirol. See Bulloch (1938), pp. 75-80; Doetsch (1960).

Stephenson, M. (1930). Bacterial Metabolism. London: Longmans, Green and Co.

Stephenson, M. (1946). The debt of biochemistry to microbiology. Congrès des sciences pastoriennes. Pur le cinquantenaire de la mort de Louis Pasteur. Paris : 18-25 Novembre, 1946. Comité du Cinquantenaire; Union Nationale des Intellectuals.

Tillet, M. (1755). Dissertation on the cause of the corruption and smutting of the kernels of wheat in the head and on the means of prevention. 1937. English translation by H. B. Humphrey. Phytopath. Class. (Amer. Phytopath. Soc.), no. 5. Ithaca, N.Y., U.S.A.

Twort, F. W. \& Ingram, G. L. Y. (1913). A Monograph on Johne's Disease. London: Baillière, Tindall and Cox.

Tyndall, J. (1881). The Floating Matter of the Air. London: Longmans, Green. See Life and Work of John Tyndall, by A. S. Eve and C. H. Creasey, 1945, London: Macmillan; Doetsch (1960).

WooDs, D. D. (1953). The integration of research on the nutrition and metabolism of micro-organisms. The Inaugural Marjory Stephenson Memorial Lecture. J. gen. Microbiol. 9, 151.

aginag

(Delivered before the Society for General Microbiology at its Thirty-second Meeting, 10 April 1961) 


\begin{tabular}{|c|c|c|}
\hline & LEVELS OF & WICROBIOLOG ICAL INVESTIGATION \\
\hline A & $\begin{array}{l}\text { mixed oultures } \\
\text { growing in natural } \\
\text { onvironments }\end{array}$ & $\begin{array}{l}\text { EARIY PASTEUR PFRIOD } 1858-- \\
\text { Early studies on ooll mieroblology, } \\
\text { \& fermentation. } \\
\text { Hodern work on marine, river \& lake pop } \\
\text { ulationa, soll \& rumlnant digestion. }\end{array}$ \\
\hline$B$ & $\begin{array}{l}\text { Pura growing eult } \\
\text { ures in laboratory } \\
\text { codis. }\end{array}$ & 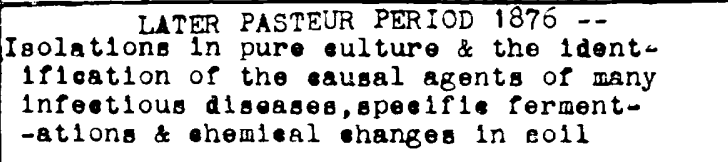 \\
\hline C & $\begin{array}{l}\text { Non-proliferating } \\
\text { eello in pure } \\
\text { eulture on ehen- } \\
\text { leslly defined } \\
\text { subatratee. }\end{array}$ & $\begin{array}{l}\text { Early studioe ( } 1919--) \text { on intermediary } \\
\text { proeesses of fermentation use of polsons, } \\
\text { inhlbitors \& flxat1ves. Early enzymes } \\
\text { studies oxidations, reductions, } \\
\text { decminations, decarboxylations ote }\end{array}$ \\
\hline D & $\begin{array}{l}\text { Pure growing eult } \\
\text { - ures in highly pur } \\
\text { - Iflod media }\end{array}$ & $\begin{array}{l}\text { Detalled otudy of growth requirements } \\
\text { nieroblal vitamins, nutritional } \\
\text { antegonism, ehomo-therapoutics, } \\
\text { mieroblologieal assay. } \\
\qquad 1930 \text { - }\end{array}$ \\
\hline $\mathbf{E}$ & $\begin{array}{l}\text { Cell-iree enzymea } \\
\text { \& ocenzymes } \\
\text { on pure } \\
\text { eubstrates. }\end{array}$ & 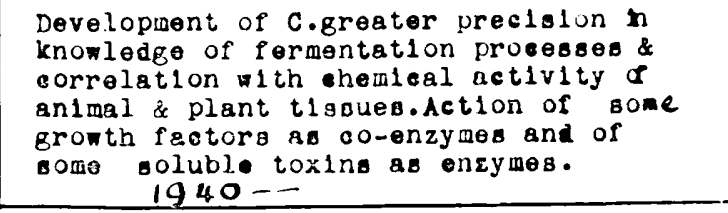 \\
\hline
\end{tabular}

Fig. 1

Unless work is to grow flrst stale and then sterile it must be refreshed by contacts with work at other levels. Moreover as knowledge increases and technique becomes more difflcult interdepartiental collaboration is strongly indicated, an development which this society may do much to foster.

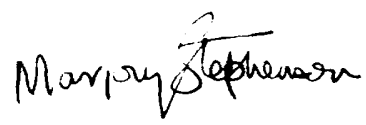

Fig. 2 